\title{
Que regime é este? The Left in Brazil, Chile and Venezuela
}

Anthony Spanakos*

\begin{abstract}
There has been considerable debate on the left in Latin America. This paper argues that the distinction between lefts is symptomatic of a larger problematic distinction in academic literature, that of regime types. The author reviews typologies presented by Juan Linz, Larry Diamond, and Peter Smith and Melissa Ziegler, before offering an alternative typology. According to that typology, Chile is an embedded liberal democracy, Brazil is a semi-embedded managed republic, and Venezuela is a semi-embedded heavily managed republic. These distinctions help not only understand the different lefts within the countries but also their.
\end{abstract}

Keywords: Typologies, Left Regimes, Economic Management.

Resumo: É recorrente o debate sobre governos de esquerda na América Latina. O presente artigo argumenta que a distinção entre alguns regimes de esquerda na referida região é sintomática e passível de crítica na literatura acadêmica. Nesse sentido, o autor resgata as tipologias de Juan Linz, Larry Diamond e Peter Smith e Melissa Ziegler, bem como apresenta uma tipologia alternativa. Conforme essa tipologia, os governos de esquerda do Brasil, Chile e Venezuela podem ser caracterizados, respectivamente, como uma democracia liberal consolidada, uma república ligeiramente "administrada" semi-consolidada e uma república excessivamente "administrada" semi-consolidada. A análise dos governos desses países ajuda-nos não somente a entender a lógica dos regimes de esquerda, mas, também, a distinção entre eles.

Palavras-chave: Tipologia, Regimes de Esquerda, Economia "Administrada". JEL Classification: $\mathrm{H} 11$; P4.

\section{Introduction}

Between December 2005 and December 2006, 11 countries in Latin America held presidential elections and the electoral results for candidates on the political left were better than at any time since the latest wave of democratization in Latin America began in 1979

* Assistant Professor at Montclair State University and Adjunct Assistant Professor at New York University, USA. E-mail: spanakos@gmail.com. The author thanks Fernando Ferrari Filho, Javier Corrales, Steve Levitsky, Sarah El-Kazaz and Michael Coppedge for their comments on this paper and earlier drafts. 
(CASTAÑEDA; NAVIA, 2007). News analysts and academics wondered whether Latin America had truly shifted to the left, what such a shift would mean, and what - after the end of the Cold War, the beginning of the war on terror, and the post-Washington consensus - the term 'left' meant.

Castañeda and Navia (2007), building on Castañeda (1994), argued that there were two lefts in Latin America: one institutional, responsible, and moderate, and one populist, anti-institutional, and combative. The distinction has been adopted by many analysts even though scholars critique it heavily. Cleary (2007) writes that the only president in Latin America who truly fits the 'populist' left model is Venezuelan president Hugo Chávez. Petras (2006), seems to agree that Chávez is the lone leftist in the hemisphere, while offering a seething critique of 'false' leftists. Interestingly enough, Castañeda told Science 8 Society that he does not "see a left" in Venezuela (CASTAÑEDA, 2005). Schamis (2006) suggests going beyond the idea of two lefts and analyzing the degree of institutionalization of the party system to explain differences among the left and Reid puts the battle in Latin America, not in terms of left or right but populists and institutio-nalists (see also REID, 2008).

Clearly, scholars are trying to explain differences within Latin America that are relatively elusive. This paper argues that social science suffers from typologies that are not adequate for comparing polities in the contemporary world. The inadequacy of these typologies has made a growth industry of creating adjectives for deficient democracies as well as for other micro and mesolevel distinctions such as between lefts, party institutionalization, and so on. This paper proposes a new typology which places Latin American countries in different spaces along continua. It then places Chile, Brazil, and Venezuela in these spaces. A more precise typology helps explain the more visible differences in party ideology and presidential behavior, among other aspects. That is, Chávez appears more populist, anti-instutionalist, and 'radically' democratic than do Brazilian and Chilean presidents Luis Inácio Lula da Silva and Michele Bachelet because he is the president of a different regime.

\section{Typologies}

Ninety countries have transitioned towards democracy in the current global 'wave of democratization' (HUNTINGTON, 1991, DIAMOND, 2008, p. 36). While in the 1980s these transitions were met with optimism, by the 1990s scholars began to find a need to address 
cases where democratization had begun but not finished. Scholars analyzing new democracies soon began to apply adjectives to democracies to explain in what way a regime missed the mark of being a 'true' democracy (COLLIER; LEVITSKY, 1997). That is, as opposed to 'parliamentary' or 'federal democracy,' regimes were labeled 'delegative' (O'DONNELL, 1999), 'illiberal' (ZAKARIA, 1997), or 'electoral caudilloist' (CLOSE, 2004), with the adjective implying what made this regime somewhat less than democratic (COLLIER; LEVITSKY, 1997, p. 431).

Without question, the significant increase in governments using mechanisms to give citizens voice overwhelmed scholars. But, as Collier and Levitsky (1997) argue, scholars should avoid simply creating new adjectives to describe particularities of one regime or one moment for a particular regime. This advice has not been heeded ${ }^{1}$ and the problems associated with analyzing contemporary regimes are reflective of a problem of typology.

The most influential typology of political regimes for much of the twentieth century was conceived by Juan Linz (2000). He distinguished Francoist Spain from Nazi Germany and the Soviet Union in terms of the source of its legitimacy and the means of organizing state-society relations, differences that were so significant that it constituted an altogether different regime type (MUNCK; SNYDER, 2007). This challenged the dominant democracy-totatilitarian typology and created the critical 'authoritarian' category which is ubiquitous today. Linz explained that authoritarian regimes could be identified by two factors: 1) "...the degree or type of limited political pluralism under such regimes" and 2) "...degree to which such regimes are based on political apathy and demobilization of the population or limited and controlled mobilizations" (LINZ, 2000, p. 54). Totalitarian governments, he argued, relied on low pluralism, but on high degrees of mobilization and ideology. ${ }^{2}$ So different were totalitarian and authoritarian governments that each could be identified as a regime and, along with democracy, they constituted the three basic forms of modern government (LINZ, 2000, p. 143). ${ }^{3}$

Though Linz was correct in separating authoritarian from totalitarian governments, his typology was clearly based on phenomena related to the modernization and urbanization taking place in the semi-developed and developing countries at the time. In retrospect,

\section{For more see Spanakos (2006).}

2 In this he differed from other scholars addressing the issue of totalitarianism who identified its uniqueness in its attempt to control the totality of its citizens' lives (Linz, 2000, p. 72).

3 A few other types of regimes existed but they were primarily 'traditional' (this included sultanistic and caudillist regimes). 
Linz's totalitarian is hardly a separate regime type, but should be considered a particular variant of authoritarian regime. The fact is, since the death of Stalin and with the exception of the Cultural Revolution in China, there have been few, if any, totalitarian regimes in the world according to his definition. If anything, totalitarian ideological and mobilizational forms tend to be ephemeral. More troubling than the use of totalitarianism as a basic type of regime is Linz's creation of multiple descriptive subtypes which overlap. For example, while the Brazilian government might easily be identified as a democracy with potential problems in 'stateness' (LINZ; STEPAN, 1996), Iran could be 'sui generis,' 'post-totalitarian,' 'totalitarian,', 'pretotalitarian,' 'post-inde-pendence mobilizational,' or even a 'pseudodemocracy.' Similarly, Venezuela could be a 'plebiscitarian democracy,' 'populist,' 'authori-tarian democracy,' 'organic democracy' or a 'majoritarian demo-cracy.' In other words, there are too many subtypes with descriptive definitions that overlap too easily. Rather than classify and organize, this typology encourages the proliferation of new categories and exaggerates the number of regime types and subtypes.

A corrective is presented by Larry Diamond, one of the most active senior scholars writing about democratization. He uses Karl's (1995) concept of hybrid regimes and Collier and Way's (2002) incorporation of competitiveness into typologies, in creating what is the most dominant typology. Beginning with a concept of democracy limited to one dimension - freedom of political opponents - he creates a continuum including liberal democracy, electoral democracy, competitive authoritarian, and noncompetitive authoritarian regimes. As one moves from liberal democracy there is an ordinal worsening of political and civil rights, as measured by Freedom House. Elections may indeed be present in all of these governments, something unanticipated by Linz (DIAMOND, 2002, p. 24), but the presence of elections does not render a regime democratic. ${ }^{4}$

Electoral democracy represents a minimal framework in which political and civil rights exist, but may not be sufficiently institutionalized to qualify as 'liberal democracy.' Thus, liberal democracy corresponds with the lowest scores in Freedom House rankings for civil and political rights (under a 2 in each category), whereas slightly higher scores correspond with electoral democracies (between 2

4 In his introductory essay (2000), rather than eliminate empty categories and refine his typology, Linz expands the number of subtypes creating more descriptive types which overlap quite significantly with existing alternatives.

5 Obviously, the scores on Peru are quite faulty and Freedom House has significantly revised their estimations. 
and 4). Diamond differentiates (see Table 1 below) Peru, the Czech Republic, and Canada as being the former, whereas Brazil, India, and the Philippines fall into the latter. ${ }^{5}$

Competitive authoritarian regimes hold elections which are less free and fair than those in electoral democracies, but they nonetheless contain the possibility of opposition victory (scoring between 4-6 on FH indicators). These are regimes where, according to Levitsky and Way, "formal democratic institutions are widely viewed as the principal means of obtaining and exercising political authority. Incumbents violate those rules so often and to such an extent, however, that the regime fails to meet conventional minimum standards for democracy" (2002, p.53). The pre-Color Revolutions Ukraine, Georgia and Kyrgyzstan are examples of this. Here, the possibility of change is almost completely absent from noncompetitive authoritarian governments without considerable opposition strength and probably also international pressure (DIAMOND, 2002, p. 24). This particular hybrid regime corresponds to what Schedler calls 'electoral authoritarianism' (2006). Though election results are not the only consideration, consistently very high electoral support for ruling parties is a tell-tale sign. Diamond cites ruling party success of "repeatedly over 95 percent in Singapore, about 80 percent in Egypt in 2000 and Mauritania in 2001, 89 percent in Tanzania in 2000, and repeated over 80 percent in Tunisia during the 1990s" (2002, p. 32) as evidence of electoral authoritarianism.

He adds two more possibilities to the original four sub-types: ambiguous regimes (somewhere between electoral democracy and competitive democracy, $\mathrm{FH}$ 3-5) and politically closed authoritarianism (FH 7). He lists the Ukraine, Nigeria and Venezuela as ambiguous regimes because there is considerable scholarly disagreement over

Table 1. Diamond's Typology of Regimes

\begin{tabular}{|c|c|c|c|c|c|}
\hline $\begin{array}{l}\text { Liberal Democracy } \\
\text { FH 1-2.0 }\end{array}$ & $\begin{array}{l}\text { Electoral } \\
\text { Democracy } \\
\text { FH }>2.0\end{array}$ & Ambiguous & $\begin{array}{l}\text { Competitive } \\
\text { Authoritarian }\end{array}$ & $\begin{array}{l}\text { Hegemonic } \\
\text { Electoral } \\
\text { Authoritarian }\end{array}$ & $\begin{array}{l}\text { Politically Closed } \\
\text { Authoritarian }\end{array}$ \\
\hline US $(1,1)$ & Argentina $(2,3)$ & Ukraine $(4,4)$ & Russia $(5,5)$ & $\begin{array}{l}\text { Kazakhstan }(6,5), \\
\text { Uzbekistan }(7,6)\end{array}$ & Turkmenistan $(7,7)$ \\
\hline Canada $(1,1)$ & Mexico $(2,3)$ & Venezuela $(3,5)$ & Malaysia $(5,5)$ & Singapore $(5,5)$ & Cuba $(7,7)$ \\
\hline Czech Republic $(1,2)$ & Brazil $(3,3)$ & Colombia $(4,4)$ & Ethiopia $(5,6)$ & Pakistan $(6,5)$ & China $(7,6)$ \\
\hline Romania $(2,2)$ & India $(2,3)$ & Indonesia $(3,4)$ & $\operatorname{Iran}(6,6)$ & Egypt $(6,6)$ & Vietnam $(7,6)$ \\
\hline Peru $(1,3)$ & Philippines $(2,3)$ & Nigeria $(4,5)$ & & & Burundi $(6,6)$ \\
\hline Taiwan $(1,2)$ & Malawi $(4,3)$ & Turkey $(4,5)$ & & & Rwanda $(7,6)$ \\
\hline \multirow[t]{2}{*}{ South Africa $(1,2)$} & & & & & $\operatorname{Iraq}(7,7)$ \\
\hline & & & & & Saudi Arabia $(7,7)$ \\
\hline
\end{tabular}

Source: Diamond (2002). 
where to put them and it seems a little too early to make a judgement. Politically closed authoritarian systems do not even make the pretense of elections and are therefore considered different.

There are some immediate conceptual problems with this scheme. To begin with, it is not clear whether the typology is designed to classify existing regimes or electoral regimes. The inclusion of 'politically closed authoritarianism' is explained because it does not fit in with the other types (it has no elections) but it is not explained in relationship to the typology. For example, there is opposition though it may have even fewer freedoms and civil rights seem less respected than the opposition in electoral authoritarian systems. But it is not clear that the existence or absence of universally considered meaningless elections justifies an additional type. The reader must wonder whether the two final types are not actually the same type in differing degrees.

The discussion of ambiguous regimes is also troubling. It is not clear whether ambiguous regimes are ambiguous because scholars disagree or because it is 'too soon to tell,' implying a transition. Diamond suggests both reasons (2002, p. 23). Scholarly agreement, however, does not seem the best explanatory factor for the meaning (nominal definition) of a type, even if it may be used in assigning cases (classificatory function). Prior to Linz's formulation of totalitarian regimes, scholars uniformly divided the world into democratic and totalitarian governments, and Diamond's use of Freedom House data led him to identify Peru under Fujimori as a liberal democracy (MUNCK; SNYDER, 2007). This is especially so since hybrid regimes by their very nature are between cases which fit snugly into neither one ideal type or the other. Thus, the label 'ambiguous' because of lack of scholarly consensus does not seem well grounded. It is better to identify regime characteristics as continuous and locate 'ambiguous' regimes on or just over the border between ideal types.

If temporality is being, the variables being measured are no longer respect for civil and political rights but the direction in which those variables, and potentially others, are seen as going. While it is important to include an indicator to accommodate change and how that might undermine or strengthen state ability and commitment in protecting rights, it is not clear that this need be included in identifying regime type. Rather, it could be (see below) a very important indicator for qualifiying how stable a regime is. After all, transitions occur in democracies (LINZ; STEPAN, 1978) and in non-democracies (O'DONNELL, SCHMITTER, WHITEHEAD, 1986). Moreover, crisis internal or not, economic, social, political, and so on - occurs in all governments and can create a new environment which is hard to judge. 
The post- September 11 era in the US changed many of the prevailing perceptions of the scope and depth of government power and citizen rights. One would hardly say that the US in 2002, or since, has been an ambiguous regime, even though scholars recognize a different environment and do not agree on its ultimate meaning.

In fact, that regimes are considered ambiguous suggests that there might be something missing from the typology. Here, not only is conceptual refinement suggested (as in the previous paragraphs) but also expansion and indexation. Levitsky and Way distinguish El Salvador, Latvia, and the Ukraine, each of which scored a combined 6 from Freedom House (counting both political and civil rights). "Yet these regimes differed in fundamental ways. Whereas in Latvia the principal undemocratic feature was the absence of citizenship rights for people of Russian descent, in El Salvador the main undemocratic features included substantial human rights violations and the absence of civilian control over the military. Ukraine possessed both universal citizenship rights and a civilian-controlled military, but civil liberties were frequently violated and incumbents routinely abused or manipulated democratic procedures" (LEVITSKY; WAY, 2002, p. 52). Since the main concern of the Diamond typology is intended to be the rights of the opposition and political rights are immediately more important in being 'electoral,' Diamond's typology should, at least, be indexed giving more weight to political rights. This would have an immediate effect on clarifying ambiguous cases and would also reduce the difference between noncompetitive regimes.

This is not to say that civil rights should not be considered. Perhaps this could also justify a case for expansion. Rather than indexing civil and political rights, Diamond could essentially separate them into two dimensions. Place barriers to political participation on one axis and recognition of universal rights of citizens might allow for El Salvador, Latvia, and the Ukraine in ways that recognized their similarity in authoritarian without losing sight of their differences.

A more recent revision of the Diamond scheme is contained in Smith (2004) and Smith and Ziegler (2008). In the latter, Smith and Ziegler distinguish regimes on the basis of how free and fair elections are, and the extensiveness of citizen rights (see Table 2). Here, Smith and Ziegler, following Zakaria (1997) and Levitsky and Way's (2002), distinguish civil and political rights. The result is a more precise classificatory system. For example, under the Diamond scheme, in 2008 (FH scores of $\{2,2\},\{1,1\}$ and $\{4,4\}$ respectively), Brazil and Chile would be both be liberal democracies (Brazil close to an electoral democracy) and Venezuela an ambiguous regime. Under the Smith 
Table 2. Smith and Ziegler's Typology of Regimes

\begin{tabular}{|c|c|c|c|}
\hline & $\begin{array}{c}\text { Citizen rights } \\
\text { expansive }\end{array}$ & Citizen rights limited & $\begin{array}{c}\text { Citizen rights } \\
\text { minimal }\end{array}$ \\
\hline $\begin{array}{c}\text { Elections free } \\
\text { and fair }\end{array}$ & Liberal democracy & Illiberal democracy & \\
\hline $\begin{array}{c}\text { Elections free } \\
\text { not fair }\end{array}$ & $\begin{array}{c}\text { Liberal/permissive } \\
\text { semi-democracy }\end{array}$ & $\begin{array}{c}\text { Illiberal/restrictive } \\
\text { semi-democracy }\end{array}$ & $\begin{array}{c}\text { Repressive semi } \\
\text { democracy }\end{array}$ \\
\hline No elections & & Moderate & $\begin{array}{c}\text { Hard-line } \\
\text { dictadura }\end{array}$ \\
\hline
\end{tabular}

Source: Smith and Ziegler (2008).

and Ziegler correction, Chile and Brazil would be liberal democracies (again Brazil close to the border), and Venezuela would be an illiberal semi-democracy.

Oddly enough, though the typology is more precise, it produces a certain amount of confusion because of mislabeling. For example, democracy is identified by how 'free and fair' elections are while 'liberalness' is identified by depth and breadth of citizen rights. But democracy is best understood by the ability (and willingness under some definitions) of citizens to participate in politics. Elections are a mechanism through which citizens may participate but they are not, in themselves, sufficient for making a regime democratic. Similarly, liberalism assumes the fundamental autonomy and irredu-cibility of the individual and the universalization of the status of the individual citizen. A regime is liberal when it respects individuals vis-à-vis minorities, it limits its own exercise of power, and all indivi-duals are treated equally before the state. The degree to which the rights of citizens are expanded or not is better identified with 'progressive' as opposed to 'liberal' politics. The Freedom House indicator for civil rights supports this critique in that civil rights are seen readings of amount of freedom within a country not progressive growth of freedom. On their webpage, they write "Civil liberties allow for the freedoms of expression and belief, associational and organizational rights, rule of law, and personal autonomy without interference from the state" and "a rating of 1 indicates the highest degree of freedom and 7 the lowest level of freedom."

Smith and Ziegler are correct in identifying democracy and liberalness as fundamental indicators, but more precise definitions and labeling are necessary. An alternative typology is proposed here 
which attempts to do this. It aims to identify regimes on the basis of how much independence citizens have vis-à-vis the regime that governs them (democraticness and liberalness). Regimes are then qualified by how embedded the type of rule, produced by the first two indicators, is.

\section{An Alternative Typology}

The Aristotelian ideal of 'ruling and being ruled' is used to identify democracy as the regime in which citizen agency is greatest. At the other extreme, is a situation where citizens are exclusively ruled and take no part in ruling. At this end, citizens are coerced by their government and have no political autonomy. As citizen agency increases, government involves citizens in minimal ways through consultation, a one-way, top-down, mechanism. There is a significant change as citizens are regularly given opportunities to choose representatives and have limited means of expressing voice and holding representatives accountable. Finally, at its strongest, distinctions between rulers and ruled evaporate as citizens are constitutive of the government itself. Such a regime is 'democratic,' since its citizens are truly ruling and being ruled. In its ideal form it exists nowhere, but lesser degrees of democracy can be found in the real world. Governments that limit citizen agency to objects of coercion or involvement in small-scale consultation are 'authoritarian' in that rule is alien to citizens. A large middle category is the 'republic' which mediates citizenship through representatives and where the amount of citizen agency varies considerably depending on local culture, history of contestation, and institutional structures. The category of 'republic' obviously contains considerable variation within it, however, combining this single variable with others allows for greater differentiation. Variation in culture, politics of contestation, and institutions effects the quality of regime performance, but does not necessarily change the regime itself.

The second variable aims to capture the amount of 'liberalness' in a society. Since Zakaria (1997) and also Pan (2006), scholars have associated universality of citizenship, the use of rule of law to protect minorities, the individualization of citizens (as opposed to communal or group definitions), and limited government with liberalism particularly in regard to recognition of a division between public and private space. No major political theorist has ever endorsed democracy without some limitation upon government and the rise of modern 
democracy is inextricably linked to the rise of liberalism (ZAKARIA, 1997). Certainly, the case for democracy, especially in a modern world would hardly be credible without some aspect of liberalism, something that was acknowledged by the Federalists and Tocqueville, among others.

What is proposed here is 'oiko-political management.' That is, how deep into the household does governance enter and to what extent are decisions that liberals consider 'private,' supervised by the government. The emphasis here is on two fundamental aspects of the household: worship and participation in the market. Freedom in these two areas is certainly correlated, but the two areas also diverge in a number of cases that are important. Economic conservatism can occur alongside religious pluralism (New Deal US) or significant management of religious practices (post revolutionary Iran). Economic liberalism seems most likely to occur alongside religious pluralism (New Labour UK) but post-Mahathir's Malaysia is an example of liberalism coexists with management of religious groups and life. These issues are especially important amidst highly controversial global debates over economic liberalization and its alternative and secularization and the rise of religious fundamentalism. Indeed, many 'ambiguous' regimes are precisely where these debates are most heated. There are many other areas of the household that can be managed by the government, for example recognition of what a household is, but these two areas are distinctive in that religious and economic liberty were the earliest and most fundamental liberties to emerge in the history of liberalism. Regimes that allow the most liberty in economic and religious decisions of individuals are 'liberal.' As regimes intervene more into these realms, they increasingly manage

Table 3. Citizen Agency and Socio-Economic Management

\begin{tabular}{|c|c|c|c|}
\hline & $\begin{array}{c}\text { Low Citizen } \\
\text { Agency }\end{array}$ & $\begin{array}{c}\text { Medium Citizen } \\
\text { Agency }\end{array}$ & $\begin{array}{c}\text { High Citizen } \\
\text { Agency }\end{array}$ \\
\hline $\begin{array}{c}\text { Low Management } \\
\text { Socio-Economic }\end{array}$ & $\begin{array}{c}\text { Liberal } \\
\text { Authoritarian }\end{array}$ & Liberal Republic & $\begin{array}{c}\text { Liberal } \\
\text { Democracy }\end{array}$ \\
\hline $\begin{array}{c}\text { Moderate } \\
\text { Management Socio- } \\
\text { Economic }\end{array}$ & $\begin{array}{c}\text { Vanguard } \\
\text { Authoritarian }\end{array}$ & Managed Republic & $\begin{array}{c}\text { Managed } \\
\text { Democracy }\end{array}$ \\
\hline $\begin{array}{c}\text { High Management } \\
\text { Socio-Economic }\end{array}$ & $\begin{array}{c}\text { Totalitarian } \\
\text { Regime }\end{array}$ & $\begin{array}{c}\text { Communitarian } \\
\text { Republic }\end{array}$ & $\begin{array}{c}\text { Command } \\
\text { Democracy }\end{array}$ \\
\hline
\end{tabular}

Source: Author's elaboration. 
citizens' oiko-political affairs and employ a concept of citizenship that is increasingly communal.

The following table locates and names the nine possibilities created by these two dimensions.

There is however, the issue of change that must be considered. For example, while Russia, China, and Malaysia all display similar types of state-society relations, the amount of legitimacy of these regimes differs considerably. All three states have undergone transitions since the late 1990s, Malaysia and China towards more open political regimes (though starting from vastly different positions) and Russia towards a more closed political regime. Of the three, the regime in Malaysia seem most stable, while there is concern about uncertainty of China's political future and the succession question pursued the Putin regime in Russia until he became prime minister. Though both are managed republics, Brazilian citizens have more potential to rule themselves than do Turks where popular sovereignty is checked by a prominent veto player (the armed forces). This limitation not only makes Turkey less republican but also affects its legitimacy, particularly for those who oppose 'secular' rule. If a system of elections consistently prescribes the choices of citizens or fails to address perceived needs, the regime will continue to be a republic, but will be a very fragile one. This was certainly the case of Venezuela in 1992 where a population that believed strongly in democracy welcomed two coup attempts (CANACHE, 2002).

Thus, the typology proposed above should be complemented by some indicator of how embedded the regime is. Social network analysts use the term 'embeddedness' to establish how deeply absorbed social networks are, how capable they are in engendering trust, norms, and producing credible expectations for social action (GRANOVETTER, 1985). Similarly, Evans (1995) argues that state performance is linked to embedded autonomy, which is dependent upon strong links between the state and networks of business sectors. Extending the idea towards typology, a regime may be considered embedded when the idea of its rule, the norms that support that rule, and the actors and institutions that are critical to that rule, have become accepted as correct and good. It is, in short, the degree to which a regime can reproduce the norms, values, institutions (formal and informal) that reinforce its rule across a given territory.

Rule may be quite stable without consensus about it being correct and good, so long as there is no compelling, realistic alternative (see HARDIN, 1989), but such a rule is not necessarily embedded. It is that particular type of regime which suddenly and drastically changes 
as was the case in Iran in 1979. Iran is instructive because the crisis of the Pahlavi regime created the possibilities for the Khomeini regime which replaced it. In fact, it is through often crises that the boundaries which will eventually define a regime are established (HAY, 1999) which is why accounting for regime change is so fundamental for understanding typologies.

Embeddedness is separated from regime type because it does not impact the type of regime but it is important in terms of identifying how stable or transitional a particular regime is. Rapid changes do occur in regime types, though it is relatively rare (SMITH; ZIEGLER, 2008, p. 39). However, regimes that are not well-embedded can and do change. Calling something a republic or a democracy does not help identify how tenable it is. Adjectival regimes can be the result of being transitional but they can also be the result of an absence of change. ${ }^{6}$ It is the task of the scholar to say that 2 years after the fall of $X$ junta this government is a republic but it is not well embedded or 20 years after the fall of the $\mathrm{X}$ junta, the government continues to have a republican structure, but it is an authoritarian regime and, moreover, that regime is embedded.

Table 4 classifies potential regimes according to this typology and it italicizes empty cells indicating regimes that are potential but nonexistent. It is based upon using Freedom House's political rights as a proxy for citizen agency, measures of economic freedom from the Heritage Foundation and restrictions on religious freedom from Brian Grim's database for liberalness, and embeddedness is a averaged score of government effectiveness and political stability as measured by the World Bank Governance Indicators. ${ }^{7}$ These indicators are imperfect but, for large $\mathrm{N}$ work, they provide enough data for reasonable classification.

There are very few embedded liberal authoritarian, embedded managed democracies, embedded managed republics, and shallow communitarian republics and there are no shallow/semi-embedded liberal authoritarian, nor semi-embedded/embedded communitarian republics, nor liberal republics or command democracies whatsoever. The most common forms tend to be embedded liberal democracies, shallow/semi-embedded/embedded managed republics, shallow/

6 Huntington (1991) considered 'hybrid regimes' to be inherently unstable but Case (2005) found ample evidence in Southeast Asia of stable hybrid regimes.

7 For Freedom House Rankings see http://freedomhouse.org/uploads/fiw/FIVVAllScores.xls. Sent to author on June 12, 2007. "Index of Economic Freedom" see http://www.heritage.org/ research/features/incex/countries.cfm. Accessed on November 11, 2007. Religious restrictions from "The Cities of God Versus the Countries of Earth: The Restriction of Religious Freedom (RRF) Index." Unpublished paper. For the World Bank Governance Indicators see note 7. 
semi-embedded/embedded vanguard authoritarian regimes, and shallow/semi-embedded totalitarian regimes. That regimes are most likely along a line that defines a positive relationship between 'citizenness' and 'oiko-political management' should not be surprising because there tends to be a strong correlation between degree of liberalness and free participation. This does not prevent the possibility of identifying more and less managed authoritarian regimes, or Table 4. Regime Types

\begin{tabular}{|c|c|c|c|}
\hline & Shallow & Semi-embedded & Embedded \\
\hline Liberal Authoritarian & Empirical compression & Empirical compression & Singapore \\
\hline $\begin{array}{c}\text { Vanguard } \\
\text { Authoritarian }\end{array}$ & Pakistan, Russia & China & Malaysia \\
\hline Totalitarian Regime & $\begin{array}{c}\text { Burma, Iran, North } \\
\text { Korea }\end{array}$ & Saudi Arabia & $\begin{array}{l}\text { Empirical/Logical } \\
\text { compression }\end{array}$ \\
\hline Liberal Republic & Empirical compression & Empirical compression & Empirical compression \\
\hline Managed Republic & $\begin{array}{l}\text { India, Nigeria, Peru, } \\
\text { Ukraine, Venezuela } \\
\quad(1999-2004)\end{array}$ & $\begin{array}{c}\text { Brazil, Mexico, } \\
\text { Mongolia, Philippines, } \\
\text { Turkey, Venezuela } \\
(2004-)\end{array}$ & Japan \\
\hline $\begin{array}{l}\text { Communitarian } \\
\text { Republic }\end{array}$ & Indonesia & Empirical compression & $\begin{array}{l}\text { Empirical/Logical } \\
\text { compression }\end{array}$ \\
\hline Liberal Democracy & Empirical compression & Empirical compression & Chile, South Korea, UK \\
\hline Managed Democracy & Empirical compression & Empirical compression & France, \\
\hline Direct Democracy & Empirical compression & Empirical compression & $\begin{array}{l}\text { Empirical/Logical } \\
\text { compression }\end{array}$ \\
\hline
\end{tabular}

Source: Author's elaboration.

allowing for the (rare) possibility of communitarian republics and managed democracies. The former are far more common than the latter, but a typology should be capable of including both without carelessly compressing them into other categories.

\section{Three Lefts or Three (Two and a half) Regimes: Chile, Brazil, Venezuela}

An empirical application of this typology to three Latin American cases is instructive. The three cases are identified as follows: Chile is considered a 'liberal democracy,' and Brazil and Venezuela are 'managed republics' though separated by considerable space. Before 
analyzing these cases, it is important to highlight the continuous nature of the variables involved here, that boundaries between 'regimes' are heuristic and not discrete. For example, the Bolivarian republic of Venezuela has 'democratic' intentions and possibilities because of the very considerable impetus given by the state, Constitution (1999), and various intermediary organizations for participation. But the efforts by the state and other actors to constrain citizen autonomy and weaken freedom of press and other freedoms cannot be discounted. The Brazilian democracy has lower levels of participation and efficacy than does Venezuela (though higher levels than Chile), but quality of participation is weakened by threats to journalists (usually from nongovernmental actors) and the poor quality of the police and courts. Participation in neither country is free enough to qualify as democratic, but the restrictions on participation are much higher in Venezuela and many of these restrictions are governmentimposed. Similarly, while the Brazilian regime has been liberalizing Table 5. Regime Types in Brazil, Chile and Venezuela

\begin{tabular}{|l|c|l|l|}
\hline & Authoritarian & Managed & Democracy \\
\hline Liberal & & Brazil & \\
\hline Semi-managed & & Venezuela & \\
\hline Managed & & & \\
\hline
\end{tabular}

Source: Author's elaboration.

for close to two decades, it continues to be one in which the state plays an important role in regulating the market. Its interference in religious matters, however, is minimal. This places Brazil towards the more 'free' section of 'managed' republics. It is clearly not as liberal as Chile, but it is far more so than Venezuela which also falls within the category of 'managed.'

\subsection{Chile: embedded liberal democracy}

Chile is an embedded liberal democracy. It consistently scores, along with Uruguay and Costa Rica, at the highest levels in terms of political and civil rights in the region. Its government is highly effective and stable and the country has witnessed 4 competitive elections whose results have been uncontested.

Prior to the 1973 coup against the Allende government, Chile had among the longest traditions of democracy in Latin America

8 The Allende government was immediately replaced by a junta led by four men. By June of the following year, Augusto Pinochet was declared head of state. 
and social democratic groups had significant influence in politics. Under the Allende government (1970-1973) participation broadened and deepened, particularly among workers' groups and leftists, and popular and government actions against private capital increased. Resistance emerged immediately and "Chile in 1973 seemed truly a nation of enemies" (BERMEO, 2003, p. 139). The Pinochet government $\left(1974^{8}\right.$-1990) was a brutal but largely liberal authoritarian government. It curtailed political rights, engaged in torture and detention against dissidents, but it also liberalized the economy and improved government efficiency. Though a climate of fear and repression prevailed, the government held referenda on its status in 1978, 1980, and 1988 which affirmed support for the Pinochet government, provided a new constitution and a phased democratization period, and rejected a continuation of the rule of Pinochet, respectively.

The mainstream opposition to the Pinochet government, consisting of parties of the center-right, center, and center-left moderated their demands to work in concert to defeat a common foe. In doing so, they forged a common political and economic agenda which recognized the successes and failures of both the Allende and Pinochet governments. The concertación of parties aimed to maintain the macroeconomic stability of the Pinochet era, but improve poverty reduction and reduce inequality, and to democratize a technically capable state, creating an institutionalized democratic system which would not overreach and threaten political stability (WEYLAND, 1999). Concertación has won every presidency since democratization and has been a model for incremental but real change (CASTAÑEDA, 1994; CASTAÑEDA; NAVIA, 2007). Most notably, it has more than halved the poverty rate between 1990 and 2006 (from 40 to 18\%), increased health spending ten-fold, maintained average economic growth of $5.6 \%$ and low inflation (below $10 \%$ since 1995 and below 4\% since 1999\%) (SIAVELIS, 2007, p. 72). It has also made considerable improvements in political terms by eliminating the unelected senators (an imposition of the Pinochet Constitution), and finding constitutional mechanisms to bringing Pinochet and others to justice.

Some of the institutional rules from the Pinochet government continue to impinge on the efficacy of participation. For example, electoral rules state that a district produce two victors and that the second candidate chosen must be from the coalition with the second highest vote total unless the winning coalition gains two-thirds of the

9 Inflation went beyond this mark in 2008. 
votes in the district (ANGELL; REIG, 2006, p. 496). This is encourages participation of the right within elections but it also decreases voter efficacy. Additionally, Chileans show low levels of interest in participation (LEVINE; MOLINA, 2007) and a relatively high level believe their system to be corrupt (CANACHE; ALLISON, 2005). But, as Canache and Allison argue, Chileans tend to exaggerate the amount of corruption. Importantly, though Chileans are far from the Aristotelian ideal in terms of actual participation, the quality of their participation is high. That is, neither the state, political parties, nor any other groups seem to impose participation or nonparticipation, the press is regarded as 'free' by Freedom House, corruption is low (ranked 22 of 180 countries by Transparency International), and the police and courts are largely non-partisan and function effectively. Thus the level of participation in Chile is on the lower edge of what might be expected in a democracy but the quality of that participation - the absence of domination over that participation - makes a strong case for Chile to be identified as a democracy.

The success of the Concertacion government in pursuing 'growth with equity' was mentioned earlier. The Concertación government has followed liberal prescriptions about a small but effective state. It is a state that did not overturn the privatization of social security accounts nor reverse voucher programs for education. It increased, but continues to target, social spending and maintained capital controls as part of a program to prevent the overvaluation of the exchange rate, to maintain export competitiveness and to encourage foreign investment. Tellingly, the Heritage Foundation ranks Chilean market to be the $8^{\text {th }}$ most free in the world, the best rating of any Latin American country.

Chile appears to be a relatively conservative country and it only legalized divorce in 2004. But religious pluralism is promoted by the state country and Chile is not nearly as conservative as it often appears. Public hospitals distribute free morning after pills, 50\% of births occur out of wedlock, and the age of consent is 14, though abortions remain illegal. It is in the area of social issues that the Bachelet government has attempted to establish its leftist credentials. Bachelet, a single mother, was elected president following a campaign which emphasized liberal rights including abortion, sex education, press freedom, more transparency of government information, and same-sex unions. Schools are required to offer twice a week religious

10 http://www.state.gov/g/drl/rls/irf/2007/90246.htm

$11 \mathrm{http}: / /$ www.state.gov/g/drl/rls/irf/2007/90246.htm 
instruction up until middle school, but participation is voluntary (Department of State 2007b). ${ }^{10}$ Also a 1999 law gives all religions the same rights that the Roman Catholic Church has in terms of chaplains in public hospitals, prisons, and the military (Department of State 2007b). ${ }^{11}$ In all, the government does not prescribe religious affiliations and has promoted an agenda which would weaken areas of traditional strength by the Roman Catholic Church.

The Chilean regime that has developed since democratization is therefore both liberal and democratic. It is also highly embedded. The opposition to Concertación finds institutional representation in conservative political parties and in civil society and it understands its role as opposition within a system, in line with Linz's conception of 'loyal opposition' (LINZ, 1978). Electoral results are not contested and politics are highly institutionalized. Moreover, the moderation of the government tends to encourage moderation on the part of the opposition (SCHAMIS, 2008). In fact, the campaign proposals of Sebastian Piñera, the candidate of the united conservative opposition, and Michelle Bachelet were remarkably similar. The World Bank Governance Indicators reflect the degree to which the regime is embedded in Chilean society. Political stability and government effectiveness are ranked on the $65.9^{\text {th }}$ and $85.8^{\text {th }}$ percentiles, respectively, nearly double the average for Latin America.

\subsection{Brazil: Semi-embedded managed republic}

The current regime in Brazil emerged as a result of a long process of abertura that began under the military regime that governed Brazil for 21 years (1964-1985). When the Brazilian military removed João Goulart from the presidency of Brazil, it was under the auspices of restoring political and economic order and thwarting the Communist threat. The Brazilian military government oversaw periods of greater and lesser repression of dissidents and systematic use of torture and, although highly critical of communist, it pursued largely statist economic policies. But the Brazilian military government was institutionalist and insisted on holding elections and compelled its opposition to compete. Regular elections during the military period attested to the institutionalized nature of military rule and the democratic pretensions of Brazil's political elite. Beginning with 1974, the opposition MDB (Brazilian Democratic Movement) won significant victories in local executive and national legislative elections. This encouraged the military to hasten their withdrawal from politics. When the first civilian president, José Sarney, entered office a constitutional 
assembly was called to refound the republic. This assembly produced a document full of political, civil, and economic rights, suggesting that decentralization of power and state-led growth were synonymous the people holding power (POWER, 2000).

Liberalization began under President Fernando Collor de Mello (1990-1992) but did not achieve any degree of policy permanence until Fernando Henrique Cardoso's real plan (1993-1994) and his presidency (1995-2002). Over that period, privatization of state owned firms, deregulation of markets, flexibilization of labor markets, and reforms of public administration aimed to holistically transform statesociety relations (SPANAKOS, 2004). Reforms, however, were piecemeal and incomplete (PINHEIRO, 2004) and largely pragmatic in orientation. Moreover, while price stabilization was very popular, privatization and other reforms were not.

Brazil's elections are free and results are uncontested. A second round is held when the leading candidate does not total more votes than the sum of his or her competitors, necessitating broad support for candidates. Similarly, the party that represented opposition, the Workers' Party (PT), committed itself to democracy from its foundation (NYLEN, 2003), operating as an organized and institutionalized expression of protest. The PT has controlled the national executive since 2003 and has maintained the system of political and economic relations of its predecessor. PT mayors, as well as others, have established popular assemblies which make decisions about public budgeting (AVRITZER, 2002) increasing the quality and quantity of political participation. Even when a breakaway group of leftists formed their own party (PSOL), the latter remained committed to the democratic system Brazil has maintained for two decades.

The Brazilian regime suffers from a perceived incapacity of the government to regulate itself. Corruption has been and remains a fundamental problem for the regime and it has worsened in recent years. Transparency International rated Brazil 72 out of 180 countries and the World Bank's control over corruption indicator has deteriorated since 2004. Congressional inquiries (CPIs) are ubiquitous and produce few convictions (they 'end in pizza' as Brazilians say) which has the effect of desensitizing voters to the issue of corruption and stripping away the moral basis for government authority. Not only have corruption scandals touched much of the national congress and most of the figures closest to president Lula, but voters in 2006 reelected so many of the figures under investigation. More direct to the lives of ordinary citizens, the Brazilian judiciary and policing systems are notoriously inefficient, unjust, and corrupt. Problems with 
the justice system effect participation by reducing the perceived efficacy as well as worsening the conditions of safety in the public sphere wherein citizens voice their complaints. The declining conditions for security weigh heavily in Freedom Housings ranking of press freedom in Brazil. It is ranked 85 and 'partly free' largely due to the threats faced by journalists from gangs as well as intimidation when investigating corruption charges. Violence also affects participation as some 90 out of 600 favelas in the country are estimated to be controlled by 'militias'. ${ }^{12}$

The Brazilian regime is quite liberal in the area of religious freedom. The Constitution establishes freedom of religion, there is no official religion, and government laws criminalize anti-semitism and racism. ${ }^{13}$ Religious groups are active in civil society and function in a plural environment exercising pressure on politicians like other organized groups. Recently, there has been an expansion of political power that is in the hands of an 'Evangelical' block among Brazilian politicians, but public culture continues to be quite liberal, serving as a space for vocal demands by women's groups and supporting parades for gay and transvestite communities.

Despite the liberalization of the exchange rate and trade, state presence remains considerable. The Heritage Foundation identifies the Brazilian market as the $101^{\text {st }}$ most economically free, placing it just below the average for the Americas. ${ }^{14}$ It particularly identifies property and labor rights, financial freedom, corruption, and government size as being evidence of government interference with economic freedom or government unwillingness and/or inability of defending property claims. As a result, it finds Brazil to be mostly unfree.

Thus, although participation in Brazil is often relatively robust it faces limitations in terms of quality because of corruption, ineffective policing by and self-policing of the government, challenges to press freedom and violence. For this reason, Brazil is considered a republic that is closer towards the border of democracy than authoritarianism. Brazil is liberal in terms of religious policies but less so in terms of economic freedoms and so it is considered a managed economy. As a result, Brazil is labeled a managed republic but is relatively close, in terms of spatial identification, to Chile.

While in Brazil all political elites accept democratic processes as 'the only game in town' (see LINZ; STEPAN, 1996), support for

$12 \mathrm{http}: / /$ www.freedomhouse.org/template. $\mathrm{cfm}$ ? page $=251 \mathcal{E}$ country $=7142 \mathcal{E}$ year $=2007$

13 http://www.state.gov/g/drl/rls/irf/2007/90244.htm

14 http://www.heritage.org/Index/country.cfm?id=Brazil 
government is weak. Political elites have done little to discourage apathy and cynicism on the part of citizens. Corruption and violence not only reduce the quality and quantity of participation, but they encourage anomie, withdrawal from the government. Moreover, the lack of government governance in spaces ranging from favelas - where government presence (if it exists) competes with non-governmental agents - to wealthy neighborhoods where civilians assume extralegal rights ${ }^{15}$ serves as an obstacle to embedding the formal, legal, and institutional rules of the regime. Finally, World Governance Indicators for political stability and government effectiveness rate Brazil at the 36.5 and $52.6^{\text {th }}$ percentiles. As such, the political system seems consolidated but government authority is based more on an absence of a competing alternative than on its own legitimacy, as the situation in many favelas suggests. For this reason, Brazil is considered a semi-embedded, relatively close to the space of embedded regimes.

\subsection{Venezuela: Semi-embedded heavily managed republic}

Unlike Chile and Brazil, or most of its Latin American peers, the Venezuelan regime is not the heir of an authoritarian government. The managed republic formed after the signing of the Pact of Punto Fijo governed Venezuela from 1958 until 1998. It was remarkable, relative to other Latin American countries, in the stability of the democratic institutions and the robust economic growth it witnessed. By the early 1980s, the embeddedness of the managed republic deteriorated rapidly as the democratic institutions became less efficacious and economic growth disappeared. The decline in regime legitimacy was further accelerated by massive rioting in February of 1989 (the Cara-cazo) and two popular coup attempts in 1992 (LÓPEZ MAYA, 2005; CANACHE, 2002; LEVINE; CRISP, 1995). Though relatively incoherent in policy proposals, over time protester demands became increasingly clear. They rejected the elitist, partycentered, and national government-dominated type of republic and the liberal politics of adjustment which had been applied in fits and starts.

Following two decades of negative economic growth and a perception of betrayal by a distant and 'false democracy,' rejection of the regime and its representatives (the traditional political parties) created a propitious situation for anti- and extra-system actors such as Lt. Colonel Hugo Chávez (KELLER, 2008). Though his direct assault on the state in 1992 was unsuccessful, his electoral campaign of 1998

15 See Roberto da Matta's writings on 'relational citizenship' in Brazil. 
was. In that campaign he promised a new constitution to create a new republic (the 'Fifth Republic') in which the power relations between state and society would be reconfigured. The Constitution incorporated elements of direct democracy and cooperative economic activities alongside traditional notions of representative democracy and mixed markets. Following his election in 1998, Venezuela has held eleven national elections and referenda. There has been an increase in political discussion and activity which offers some validation to the Constitutional claim to be a "protagonist and participatory democracy" (GARCÍA-GUADILLA 2003). But there have been significant constraints in the protection of the autonomy of participants in the political process as well, the result of state action, its supporters and opponents, and criminals.

The regime of president Chávez claims to be moving towards (and creating) $21^{\text {st }}$ Century Socialism. Since 1999, but especially since 2002, the government produced rhetoric and then policies which aim to increase state control over the economy and has used the resources of the state to encourage and extort private economic agents. This is seen, by the regime, as both a 'recovery' of space lost during the 'neoliberal' period as well as a necessary step towards socialism.

The Bolivarian Republic of Venezuela under Hugo Chávez is very difficult to categorize but it may best be considered a heavily managed republic. It is a republic because it has both very high levels of democraticness in terms of participation and spaces for participation, but the quality of participation in these spaces and the regular rejection of spaces that produce dissent reduces the efficacy of participation. The number of elections that has taken place over the past decade in Venezuela is astounding. President Chávez and his supporters are correct in using the relatively constant electoral cycle as a basis for comparison with the 'Fourth Republic' where "you voted once every five years and then went home." ${ }^{16}$ Additionally, these votes included referenda on having a constituent assembly, the new constitution, recalling the president, and two sets of sweeping amendments to the Constitution. Consistent with a vision of citizens directly participating in decisions that would impact the way political power effects their lives, the current Venezuelan regime has created considerable space for participation. It has also created local political

16 Interview with a teacher, Barquisimeto, Venezuela, 5 March 2008.

17 During field research conducted between January and July of 2008, both supporters and opponents of the government recognized that since Chávez poor people are talking about politics more and are more aware of their rights. 
units, communal councils, which unite activities of diverse neighborhood groups (MAINGÓN; SOSA ABASCAL, 2007) and given them a specific institutional space within the division of powers and resources in the republic. Most importantly, it has enabled and facilitated the agency of many among the poor in Venezuela to engage in political discussions, contestation, and decision-making. ${ }^{17}$ These aspects are reflective of the importance of 'direct democracy' and the ideal of a 'protagonist' citizenry in the ideology of the new regime.

At the same time, president Chávez regularly resorts to polarizing the citizenry between the 'people' and its 'enemies.' This involves not only rhetorical attacks on political opponents, corporations, and the United States and its allies, but also on dissident voices that identify themselves as part of Chavismo. The government used its resources to stall, delegitimize, and prevent the recall referendum by challenging the veracity of the signatures collected and, eventually, publishing a list which included the names and identification numbers of the people who supported the recall (the Lista Tascon). That this list was used as a means by government agencies to discriminate was recognized even by the president who said, in a conciliatory moment in 2006, "That's over. Bury Tascon's List. Surely it had an important role at one time, but not now" (MURPHY, 2006; CORRALES; PENFOLD 2007). Moreover, after leaving the presidency of the National Electoral Council, a nonpartisan position, Jorge Rodriguez accepted the position of vice president of the Republic, and is now the president of the party of Hugo Chávez, and a candidate for mayor of one of the municipalities in Caracas. Not surprisingly, Venezuelans, particularly opponents of the regime, doubt the secrecy of the ballot (KELLER, 2008). The questions about the non-partisan nature of the CNE is extended to all branches of government included the Supreme Court and the Controller's office. Chávez increased the size of the former from 20 to 32 members creating an automatic majority. The latter is responsible for identifying politicians who are unable to run for office (due to charges proven against them). During the local campaigns in 2008, the controller's office was in the midst of a huge controversy as over 250 candidates, mostly of the opposition, were declared ineligible. This included the candidate leading the polls for the mayorality of Caracas. Protesters wore tshirts with the message "respect the Constitution" and "I decide my vote" and they marched on both the Controller's office and to the Supreme Court to defend their political rights.

There are also many concerns about the communal councils. President Chávez has spoken of 'changing the geography of power' 
and empowering local communities, but the councils are designed in such a way to make local communities less dependent upon municipal governments but more directly dependent upon the national executive (MAIGNÓN; SOSA ABASCAl 2007). The new geometry, one of the potential amendments rejected in the Constitutional Referendum of 2007, places the national council of communal councils under the presidency and places the state level and local community councils beneath that. Not only are communal councils then vertically linked to the presidency but a communal council cannot be a 'communal council' unless it is recognized as such by agents of the executive branch. The councils are not units that are assigned to geographic spaces but are groups of families which organize and are then recognized by the state. Obviously, this is a tremendous deterrent for participation among those who are not partisans of the government. ${ }^{18}$

Participation has also been limited, particularly between 2001 and 2004, by the presence of armed bands supported by the government and its more radical opponents. From 11-13 April 2002, in the most extreme form of curtailing the effectiveness of participation, some within the opposition removed the president from office and set up an interim government after the military fired upon civilian demonstrators. The coup is the most extreme example of such activities, but smaller scale intimidation at rallies has occurred as well. Additionally, street criminals also play a very important role in limiting participation. Given that the regime identifies its legitimacy by encouraging 'parliamentarism in the streets,' public spaces must be safe and plural to make such parliamentarism possible. The regime and its opponents may be blamed for the limits of pluralism in public space, but violent crime is an important deterrent in terms of any activity in the streets particularly because much of civil society action revolves around meetings and discussions after work hours when cities are far more dangerous, especially in the barrios (shantytowns).

Finally, the environment in which the press functions also affects the quality of participation. Defenders of the regime are correct to say that there is freedom of the press in Venezuela in that many opponents of the regime critically express their opinions publicly

18 The leader of a potential community council reported that she has been petitioning various government agencies and they constantly tell her that the paperwork is insufficient and that she should go to another agency. The process for "Chavista" councils, she reports, is much easier.

19 One public intellectual said his phone had been bugged but the government never directly limited him. Though he knew of cases where it did. 
and have not been threatened by the regime. ${ }^{19}$ But the government, particularly the president, regularly identifies media corporations and journalists who are 'unpatriotic,' 'lying,' 'terrorists,' and 'enemies of the state.' In 2007, Chávez refused to reissue a public license for RCTV the oldest broadcaster in Latin America. The government explained that it wanted to use the license for a station that would be more in the public interest and promote national programming, not for supporting a station which played telenovelas and imported foreign television series. But months before the license expired the president announced on national television that he would not reissue the license because it was a 'coup supporting' channel (JIMÉNEZ, 2008). During the first four months of 2008, the president and his ministers regularly attacked the 'mediatic war' against them, particularly the 24/7 news channel Globovision. This station was threatened by the president on a weekly basis on his television show, in the National Assembly, and by the government tax authority. Pro-government 'civil society' painted graffiti throughout Caracas calling the station "globoterrorism" and a former police officer was found leaving explosives outside its office.

Though the government is careful not to engage in censorship in any obvious manners, it creates a perpetual environment of threat. These threats are institutionally validated by the denial of state resources for projects which feature 'opponents' of the regime and by the Law of Responsibility of Radio and Television which criminalizes vaguely defined irresponsible behavior by journalists.

For this reason, evaluating participation in Venezuela is somewhat bipolar in that it contains very high potential and actual mechanisms for participation associated with democratic regimes as well as significant punitive mechanisms within a non-transparent institutional environment that is more typical of an authoritarian government. Venezuela is best understood as a republic because there are real possibilities for efficacious participation, as seen by the rejection of the referendum in 2007, but these possibilities can easily be rejected by a very powerful government, as seen by the government's reaction to the referendum. ${ }^{20}$

While the identification of the Bolivarian Republic as a republic elicits criticisms from regime proponents and opponents alike, there is little question about whether the regime is liberal. Its understanding of political and civil rights and the neutrality of government institu-

20 Not its 'recognition' of the opposition's victory, which was broadcast across the world as evidence of Chávez's democratic nature, but the continuation with virtually all of the elements which had been contained within the referendum which was rejected.

21 http://www.state.gov/g/drl/rls/irf/2007/90271.htm 
tions, as seen above, suggest it is not at all a liberal regime. It is quite liberal in terms of religious tolerance although the hierarchy of the Roman Catholic Church has been very critical of the government and has been pressured by the regime and its opponents. ${ }^{21}$ But this pressure is largely of a political nature and the government does not endorse and reject any particular religion. That said, president Chávez, on his national television show, regularly engages in contextualizing Old Testament figures and Jesus Christ within the ethics of his socialist, anti-capitalist, and anti-oligarchic positions. He often invites renegade Roman Catholic priests inspired by liberation theology to validate his musings on the subject. Though Chávez has a close friendship with Iranian president Ahmadinejad (DODSON; DOORAJ 2008) and has negatively compared Colombia to the state of Israel, he has spoken in favor of the existence of the state of Israel and seems against antiSemitism within Chavismo (ELLNER, 2007).

Where the regime is decidedly anti-liberal is in the area of economic policy. This is not surprising given Chávez's original economic ruminations were profoundly anti-neoliberal and semi-structuralist and that, since 2005, he has declared his intentions to be socialist. Regardless of the ambiguity surrounding $21^{\text {st }}$ Century Socialism (LOPEZ MAYA, 2007), he has been clear about pressuring domestic and foreign private corporations, invited foreign state-owned corporations to be part of mixed partnerships, and has recently engaged in the nationalization of the phone company, electrical company, various petroleum projects, and a major cement company. Monetary policy is thoroughly managed by the government which generally pursues considerably expansionary policies and then suddenly contracts sharply when inflation rises (as was the case in early 2008). The foreign exchange rate is very overvalued, it is now criminal to discuss or publish a rate other than the official exchange rate, and Venezuelans must apply for permission to purchase dollars at the official exchange rate. Like monetary policy, fiscal policy has been excessively procyclical.

Venezuela under Hugo Chávez is an increasingly managed republic, one that maintains significant tensions between democratic and authoritarian tensions. Ironically, it is not these tensions that prevent the system from being embedded. Rather it is the very significant resistance of, at least, a large minority to the policy style and direction of the regime. That said, tensions were much higher between 1999 and 2004, especially beginning in 2001 when the National Assembly gave Chávez wide-ranging 'enabling powers' which allowed him to circumvent the Assembly. Over the next few years, the government suffered a decline in popularity, a coup, a 
three-month long strike among petroleum workers and a recall referendum. By late 2003, government popularity began to recover and, with the increase in petroleum revenues, the government was able to increase social spending and establish its 'pro-poor' identity. Since the very serious defeat of the recall referendum in 2004, government opponents seem to accept the government as legitimate, even while considering it detestable. The opposition boycotted the elections of 2005 but competed in the presidential elections in 2006 and triumphed in the referendum of 2007. During this time, the 'loyal' members of the opposition have gained ground versus the 'disloyal' ones, or rather, opponents who favored institutional challenges to the regime gained space over those who favored extra and anti-institutional means. This, however, does not mean that anti-institutional means have been ruled out or that political elites, analysts, and, even the president himself, do not discuss the possibility of his being removed from or resigning from office before 2013 (when his mandate ends) or his maintenance in office beyond 2013 (which, at this point, would be unconstitutional). Given the relative stability and acceptance, or at least tolerance, of the current regime, resulting from numerous elections and victories over very real challenges to its legitimacy, the regime has a semi-embedded status. It continues to be semi-embedded because the president has radicalized his agenda at points when opposition waned, which quickened more radical members of the opposition, and because the regime is entirely centered on the figure of president Chávez who is (for now) unable to run for the presidency in 2012, creating a succession problem.

\section{Final Considerations}

Do Bachelet, Lula, and Chávez represent different 'lefts,' is one of them the 'real left,' are some more 'left' than the others? These are very important questions for analysts and scholars. But the fact that these questions emerge allows broader, more macrolevel questions to surface. Scholars engaging in comparative inquiry have been in the uncomfortable position of trying to understand and explain politics, economics, and social problems in a world full of countries that increasingly use elections as a means of legitimating regimes. This has problematized many typologies which assign labels such as democracy and authoritarian, leading to a rather anarchic proliferation of adjectival regimes. Recent efforts to impose a classificatory order by scholars such as Diamond (2002), Levitsky and Way (2002), and Smith and Ziegler (2008) are important in identifying weaknesses in 
the literature and possible solutions. This essay builds on their work to offer a typology which can account for greater differences within regimes as well as identifying their relative legitimacy.

Using this typology, the Chilean government is an embedded liberal democracy and the Brazilian and Venezuelan governments are semi-embedded managed republics. However, the variables used here are continuous and Venezuela and Brazil are rather distant in terms of quality of citizen participation and how liberal and embedded the regime is, with the Brazilian government having a significantly higher degree of each of these variables than its Venezuelan counterpart. This helps not only understand Bachelet, Lula, and Chávez, but also their opponents, the choices of their electorates, and the potential for change within each country. That is, this typology aims to help organize a universe of political data in a meaningful way. It should be noted that it does not do so with any explicit preference of with any explicit for one type of regime over another. It merely aims to link together regimes that have like dynamics in terms of citizen autonomy and government management.

\section{References}

ALMOND, G. A.; VERBA, S. The Civic Culture: Political Attitudes and Democracy in Five Nations. Princeton: Princeton University Press, 1963.

ANGELL, A.; REIG, C. Change and Continuity? The Chilean Elections of 2005/2006. Bulletin of Latin American Research, v. 25, n. 4, p. 481-502, 2006.

AVRITZER, L. Democracy and the Public Space in Latin America. Princeton: Princeton University Press, 2002.

BERMEO, N. Ordinary People in Extraordinary Times: The Citizenry and the Breakdown of Democracy. Princeton: Princeton University Press, 2003.

CANACHE, D. From Bullets to Ballots: The Emergence of Popular Support for Hugo Chávez. Latin American Politics and Society, v. 44, n. 10, p. 69-90, 2002.

CANACHE, D.; ALLISON, M. E. Perceptions of Political Corruption in Latin American Democracies. Latin American Politics and Society, v. 47, n. 3, p. 91-111, Fall 2005.

CASE, W. Southeast Asia's Hybrid Regimes: When Do Voters Change Them? Journal of East Asian Studies 5, 2005.

CASTAÑEDA, J. G. Utopia Unarmed: The Latin American Left After the Cold War. New York: Random House, 1994.

. Realism for Latin America: Achieving the Possible. Science 8 Society, v. 69, n. 2, p. 138-142, april 2005.

CASTAÑEDA, J. G. and NAVIA, P. The Year of the Ballot. Current History. february 2007, p. 51-57.

CLEARY, M. Explaining the Left's Resurgence. Journal of Democracy, v. 17, n. 4, p. 35-49, october 2007.

CLOSE, D. Undoing Democracy in Nicaragua. In: David Close and Kalowatie Deonandan 
(ed.). Undoing Democracy: The Politics of Electoral Caudillismo. Lanham: Lexington Books, 2004.

COLLIER, D.; LEVITSKY, S. Democracy with Adjective: Conceptual Innovation in Comparative Research. World Politics, april 1997.

CORRALES, J.; PENFOLD, M. Venezuela: Crowding Out the Opposition. Journal of Democracy, v. 18, n. 2, p. 99-113, april 2007.

DIAMOND, L. Elections without Democracy: Thinking About Hybrid Regimes. Journal of Democracy, v. 13, n. 2, p. 21-35, 2002.

. The Resurgence of the Predatory State. Foreign Affairs. p. 36-48, march/april 2008.

DODSON M.1; DOORAJ, M. Populism and Foreign Policy in Venezuela and Iran. The Whitehead Journal of Diplomacy and International Relations, IX (1), p. 71-87, winter/ spring 2008.

ELLNER, S. Toward a 'Multipolar World': Using Oil Diplomacy to Sever Venezuela's Dependence. NACLA Report on the Americas, v. 40, n. 5, september/october, 2007.

FREEDOM HOUSE. Methodology Freedom in the World. 2008 Edition. Available in: $<$ http://www.freedomhouse.org/template.cfm?page=351Eana_page $=341$ Eyear $=2008>$. Accessed on: 10 july 2008 .

GARCIA-GUADILLA, M. P. Civil Society: Institutionalization, Fragmentation, Autonomy. In: STEVE E.; DANIEL H. (ed.), Venezuelan Politics in the Chávez Era: Class, Polarization \& Conflict. Boulder: Lynne Rienner Publications, 2003.

GRANOVETTER, M. Economic Action, Social Structure, and Embeddedness. American Journal of Sociology, v. 91, p. 481-510, 1985.

HARDIN, R. Why a Constitution In: Bernard Grofman and Donald Wittman (ed.), The Federalist Papers and the New Institutionalism. New York: Agathon Press, 1989.

HAY, C. Crisis and the structural transformation of the state: interrogating the process of change. British Journal of Politics and International Relations, v. 1, n. 3, p. 317-344, 1999.

HUNTINGTON, S. P. Democracy's Third Wave. Journal of Democracy, v. 2, n. 2, spring 1991. JIMÉNEZ, S. La historia de TV nacional sale del aire. El Universal. 5 february 2008, p. 3-12. KARL, Terry Lynn. The Hybrid Regimes of Central America, Journal of Democracy, n. 6 , p. 72-86, july 1995.

KELLER, A. Cultura y Juegos de Poder. Unpublished draft January 2008.

LEVINE, D. H.; CRISP, B. F.. Legitimacy, Governability, and Reform in Venezuela. In: Louis W. Goodman, Johann Mendelson Forman, Moisés Naím, Joseph S. Tulchin and Gary Bland (ed.). Lessons of the Venezuelan Experience. Washington, D.C. 1995.

LEVINE, D.; MOLINA, J. La Calidad de la Democracia en America Latina: una visión comparada. América Latina Hoy, 45, p. 17-46, April 2007.

LEVITSKY, S.; WAY, L. The Rise of Competitive Authoritarianism. Journal of Democracy, V. 13, n. 2, p. 51-65, april 2002.

LINZ, J. J. Totalitarian and Authoritarian Regimes. Boulder: Lynne Rienner, 2000.

LINZ, J. J.; STEPAN, A. Crisis, Breakdown, and Re-equilibration. Baltimore: The Johns Hopkins University Press, 1978.

. Problems of Democratic Transition and Consolidation: Southern Europe, South America, and Post-Communist Europe. Baltimore: The Johns Hopkins University Press, 1996.

LÓPEZ MAYA, M. De viernes negro hasta el referendo revocatorio. Caracas: Editorial Alfadil, 2005 . 
Alfa, 2007.

. (ed.). Ideas para debatir el socialismo del siglo XXI. Vol. I, Caracas: Editorial

MAINGÓN, T.; ABASCAL, A. S. Los consejos comunales: ¿Espacios para la construcción de ciudadanía y el ejercicio del poder popular? p. 14. Draft 22 May 2007.

MUNCK, G. L.; SNYDER, R. Passion, Craft and Method in Comparative Politics. Baltimore: Johns Hopkins University Press, 2007.

MURPHY, H. Chavez's Blacklist of Venezuelan Opposition Intimidates Voters. Avaible on: < http://www.bloomberg.com/apps/news?pid=10000086Essid=abASlsAyXgoEErefer $=$ newsindex $>$. Accessed on: 21 July 2008.

NYLEN, W. R. Participatory Democracy versus Elite Democracy: Lessons from Brazil. New York: Palgrave Macmillan, 2003.

O’DONNELL, G. Counterpoints: Selected Essays on Authoritarianism and Democracy. South Bend: University of Notre Dame Press, 1999.

O'DONNELL, G.; SCHMITTER, P. C.; WHITEHEAD, L. (ed.). Transitions from Authoritarian Rule. Baltimore: The Johns Hopkins Press, 1986.

PAN, W. Toward a Consultative Rule of Law Regime in China. In: Suisheng Zhao (ed.). Debating Political Reform in China: Rule of Law us. Democratization. Armonk: M.E. Sharpe, 2006.

PINHEIRO, A. C.; BONELLI, R. and SCHENEIDER, B. R. Pragmatic policy in Brazil: the political economy of incomplete market reform. Texto para discussão n. 1035. Rio de Janeiro: Instituto de Pesquisa Econômica Aplicada, 2004.

PETRAS, J. 'Centre-Left' Regimes in Latin America: History Repeating itself as farce. Journal of Peasant Studies, v. 33, n. 2, p. 278-303, april 2006.

REID, M. Forgotten Continent: The Battle for Latin America's Soul. New Haven: Yale University Press, 2008.

PAN, W. Toward a Consultative Rule of Law Regime in China. In: Suisheng Zhao (ed.). Debating Political Reform in China: Rule of Law us. Democratization. Armonk: M.E. Sharpe, 2006.

POWER, T. Political Institutions in Democratic Brazil: Politics as a Permanent Constitutional Convention. In: Peter Kingstone and Timothy Power (ed.). Democratic Brazil. Pittsburgh: University of Pittsburgh Press, 2000.

SCHAMIS, H. E. Populism, Socialism, and Democratic Institutions. Journal of Democracy, v.17, n. 4, p. 20-34, october 2006.

SIAVELIS, P. How New Is Bachelet's Chile? Current History, v. 106, n. 697, p. 70-76, February 2007.

SMITH, P. H. Democracy in Latin America: Political Change in Comparative Perspective. New York: Oxford University Press, 2004.

SMITH, P. H.; ZIEGLER, M. Liberal and Illiberal Democracy in Latin America. Latin American Politics and Society, v. 50, n. 1, p. 31-57, spring, 2008.

SPANAKOS, A. P. Reforming Brazil: A preliminary assessment. In: Mauricio Font and Anthony Peter Spanakos (ed.). Reforming Brazil. Lanham: Lexington Books, 2004.

Adjectives, Asterisks and Qualifications, or How to Address Democracy in Contemporary Latin America. Latin American Research Review, v. 42, n. 2, June, 2007. WEYLAND, K. Economic Policy in Chile's New Democracy. Journal of Interamerican Studies and World Affairs, v. 41, n. 3, p. 67- 96, Fall, 1999.

ZAKARIA, F. The Rise of Illiberal Democrac. Foreign Affairs. November/December, 1997. 
